\title{
3401 酸化第二鉄の塩化揮発速度について
}

\section{1. 緒言}

鉄鉱石処理の一方法として塩化水素ガスによる塩化揮

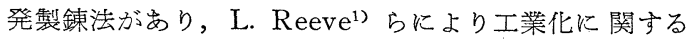
検討がなされている。この方法の基礎的な反応式は

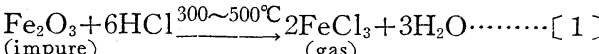

$$
\begin{aligned}
& \underset{\text { (gas) }}{2 \mathrm{FeCl}_{3}}+3 \mathrm{H}_{2} \mathrm{O} \stackrel{500 \sim 600^{\circ} \mathrm{C}}{\longrightarrow} \underset{\text { (pure) }}{\mathrm{Fe}_{2} \mathrm{O}_{3}}+6 \mathrm{HCl}
\end{aligned}
$$

である。[1]の段階で鉱石中の酸化第二鉄を塩化第二鉄 ガスとして揮発させ，これを[2]の段階で水蒸気を吹込 むことにより純度の高い酸化第二鉄および塩化水素ガス を回収する。塩化水素ガスは乾燥後再び [ 1 ] 段階の反応 に用いることができる。著者らはパイライトシンダー中 の有用金属々酸化鉄をこの方法で分離することを目的と して実験を進めているが，本報告は酸化第二鉄について [1]段階の塩化揮発反応速度を熱天科により検討したも のである。

\section{2. 試料および実験方法}

試料々して用いた酸化鉄は知床産褐鉄鉱のうち比較的 純度の高いものを16 20mesh に粉砕し， $800^{\circ} \mathrm{C}, 5$ 時間 焙焼して完全に脱水および脱硫を行ない, $\alpha \mathrm{Fe}_{2} \mathrm{O}_{3}$ とし実 験に供した。試料の分析值は $\mathrm{Fe}_{2} \mathrm{O}_{3}-93.7 \%, \mathrm{FeO}-0.01$ $\%, \mathrm{SiO}_{2}-6.0 \%, \mathrm{~K}-\mathrm{tr}$. である。使用した熱天科は石 英ズプリング型のもので, 温度制御は土 $3{ }^{\circ} \mathrm{C}$ 以内にとど めた。スプリングは $3 \mathrm{~g}$ 用を使用し，カセトメータの 1 目盛が $0.576 \mathrm{mg}$ にあた。バスケットは内径 $15 \mathrm{~mm}$ の石 英管を高さ $2 \mathrm{~mm}$ に薄く輪切りにし, 底部を細い石英棒 にて十文字に熔着させ，その上に石英ウールを薄く敷い たものである。ガス境膜拡散と堆積層の影響を除くため にあらかじめ予備実験をして実験条件をつぎのように決

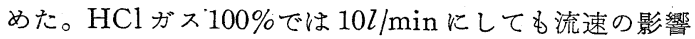
が残るので， $\mathrm{HCl}$ ガス中に $\mathrm{N}_{2}$ ガスを混入して $\mathrm{HCl} 40 \%$ 以下にしたところ $4 \mathrm{l} / \mathrm{min}$ 以上で反応率は一定となつた ので, $\mathrm{HCl} 20 \mathrm{vol} \%$, 流速 $6 l / \mathrm{min}$ で実験した。粒径に関 しては $20 \mathrm{mesh}$ より犬きな粒子では固体内拡散抵抗の恐 れがあり，100mesh以下では試料量の関係から堆積層の 影響が避けられないので 35〜 48mesh とした。試料量は $0.6 \mathrm{~g}$ 以下で35 48meshの場合反応率は一定となるので $0.5 \mathrm{~g}$ とした。この量はバスケット内に粒子がちようど 一列に並んだ状態である。

\section{3. 結果および考察}

塩化揮発反応の開始温度を求めるため連続昇温による 重量変化を測定した。常温から増量が始まり $200^{\circ} \mathrm{C}$ 付近 をピークとして減量しはじめ以後試料が消失するまで減 量が続いた。240〜 $500^{\circ} \mathrm{C}$ の各温度に打ける減量変化率を 時間に対してプロットしたものが第 1 図の点が示す曲線 である。反応途中の残查をX線回折ならびに化学分析で 調べた結果, 未反応の $\mathrm{Fe}_{2} \mathrm{O}_{3}$ の他に $\mathrm{FeCl}_{3} \cdot 6 \mathrm{H}_{2} \mathrm{O}$ 扰よび

$\begin{array}{lrlll}\text { 北海道工業開発試験所 } & \text { ○佐 } & \text { 藤 } & \text { 享 } & \text { 司(正会員) } \\ \text { 北海道工業開発試験所 } & \text { 鈴 } & \text { 木 } & \text { 良 } & \text { 和 } \\ \text { 北海道工業開発試験所 } & \text { 佐 } & \text { 山 } & \text { 惣 } & \text { 吾 }\end{array}$

微量の $\mathrm{FeCl}_{2} \cdot 6 \mathrm{H}_{2} \mathrm{O}$ の存在が認められた。

実験はガス境膜拡散の影響を無視できる条件で行なつ たので，ここでは固体内拡散々化学反応速度についての み考察した。反応は石炭の然焼モデルと類似しているの で，それについての矮ら ${ }^{2)}$ の応式をもつて検討する と実験の高温部分の反応曲線は明らかに反応律速の式に 一致している。また藤重引の導いた非定常に打ける固体 内拡散々化学反応速度の総括反応速度式を用いて先の実 験結果を検討すると反応律速とみなせる。しかしこれら の式では第 1 図に示す反応率曲線の初期において上に山 であることを説明できない。そこで実験結果を解析する ためにつぎの仮定に基いて速度式を組立てた。

（1）反応はまず固体状の塩化物が生成し，つぎにガ ス体の塩化物になる逐次反応である。

（2）塩化反応は反応界面積とガス濃度に比例する。

（3）分解反応は固体状の塩化物の量に一次に比例す る。

（4）分解反応速度は塩化反応速度と比較して犬であ る。

$$
\begin{aligned}
& -\frac{d W_{1}}{d t}=A k_{1}\left(C-C^{*}\right) \\
& \frac{d m_{3}}{d t}=k_{2} m_{2}
\end{aligned}
$$

（4）を（1）に代入して積分し $m_{1}$ で整理すると

$$
m_{1}=(1-K t)^{3}, K=\frac{k_{1}\left(C-C^{*}\right)}{R \rho}
$$

（3）と（5）を（2）に代入して

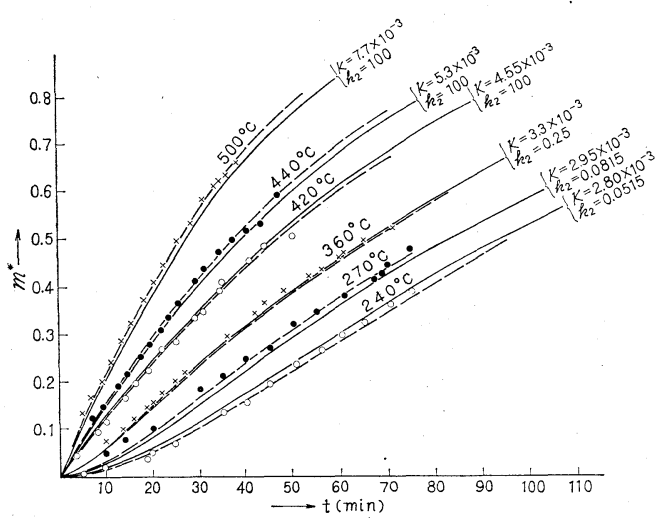

第 1 図 減量変化率曲線 


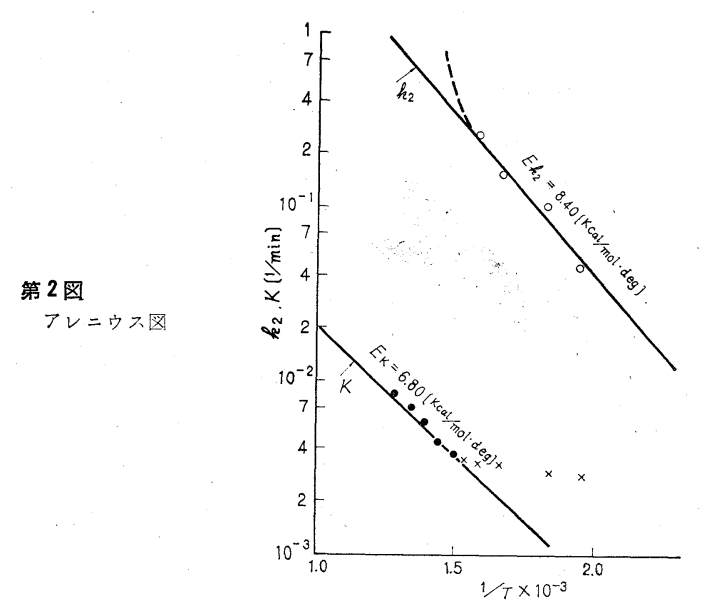

$$
\frac{d \alpha m_{3}}{d t}=k_{2}\left\{1-(1-K t)^{3}-\alpha m_{3}\right\}
$$

$t \leqq \frac{1}{K}$ の場合, 積分すると

$$
\begin{aligned}
\alpha m_{3}= & \frac{3 K}{k_{2}{ }^{3}}\left\{k_{2}{ }^{2}+2 k_{2} K+2 K^{2}\right\} e^{-k_{2} t} \\
& -\frac{1}{k_{2}{ }^{3}}\left\{k_{2}{ }^{3}(1-K t)^{3}+3 k_{2}{ }^{2} K(1-K t)^{2}\right. \\
& \left.+6 k_{2} K^{2}(1-K t)+6 K^{3}-k_{2}{ }^{3}\right\} \cdots \cdots \cdots(
\end{aligned}
$$

$t \geqq \frac{1}{K}$ の場合には

$$
\begin{aligned}
\alpha m_{3}=1 & -\left\{\frac{6 K^{3}}{k_{2}{ }^{3}}-\frac{3 K}{k_{2}{ }^{3}}\left(k_{2}{ }^{2}+2 k_{2} K+2 K^{2}\right) e^{-\frac{k_{2}}{K}}\right\} \\
& e^{-k\left(t-\frac{1}{K}\right)} \ldots \ldots \ldots \ldots \ldots \ldots \ldots \ldots \ldots \ldots \ldots \ldots \ldots \ldots \ldots \ldots \ldots \ldots
\end{aligned}
$$

ここで仮定 (4) により $W_{2}$ が $W_{0}$ より非常に小さけれ ば,

$$
\alpha m_{3} \doteqdot m^{*}
$$

が成立し，熱天科の減量率を $\alpha m_{3}$ で示すことができる。 そこで（7）式と（8）式を用いて数值代入法により第 1 図の破線のような反応率曲線を画き，点で示される実 際の減量率曲線との一致から $K$ と $k_{2}$ を求めた。これをつ レニウスプロットしたものが第 2 図である。ここでKは ×印で示したように $380^{\circ} \mathrm{C}$ 以下では勾配が小さくなり， $k_{2}$ は $400^{\circ} \mathrm{C}$ 以上で急激に増加し， $k_{2} \gg K$ となる。このこ とから $380^{\circ} \sim 400^{\circ} \mathrm{C}$ を境として反応形態が全く一変し， 見かけ上同じ速度式ではあるがその内容は別の機鏳にあ ると推定される。

第 1 図の実線はアレニウスプロットの勾配から算出し た各温度の反応率曲線で，実測值のバラッキを考慮する

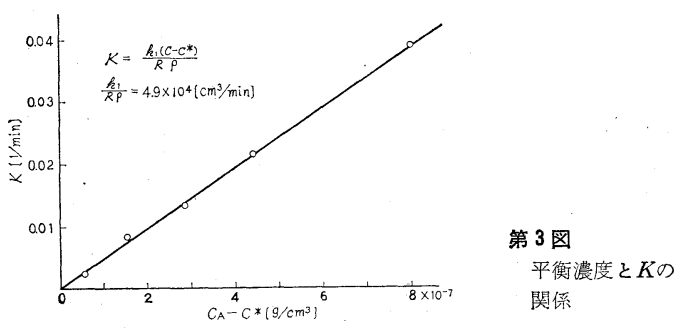

とこの程度に落着くものと思われる。

V. H. Schäfer ${ }^{4)}$ によば $600^{\circ} \mathrm{C}$ 以下では

$\mathrm{Fe}_{2} \mathrm{O}_{3}+6 \mathrm{HCl}=\mathrm{Fe}_{2} \mathrm{Cl}_{6}+3 \mathrm{H}_{2} \mathrm{O}$

の反応式で平衡定数 $K_{p}$ は

$$
\log K_{p \mathrm{Fe}_{2} \mathrm{Cl}_{6}}=-11.853+\frac{340}{4.57 T}
$$

の值である。これから $500^{\circ} \mathrm{C} て ゙ \mathrm{HCl}$ 各濃度の $\left(C-C^{*}\right)$

\begin{tabular}{|c|c|c|}
\hline A & 表面積 & $\mathrm{cm}^{2}$ \\
\hline$C$ & 塩化水素ガス濃度 & $\mathrm{g} / \mathrm{cm}^{3}$ \\
\hline$C^{*}$ & 塩化水素ガス平衡濃度 & $\mathrm{g} / \mathrm{cm}^{3}$ \\
\hline$K$ & $k_{1}\left(C-C^{*}\right) / R \rho$ & $1 / \mathrm{min}$ \\
\hline$k_{1}$ & 塩化反応速度定数 & $\mathrm{cm} / \mathrm{min}$ \\
\hline$k_{2}$ & 分解反応速度定数 & $1 / \mathrm{min}$ \\
\hline$r$ & $t$ 時間後に搁ける反応界面までの半径 & $\mathrm{cm}$ \\
\hline$t$ & 時 間 & $\min$ \\
\hline$W_{0}$ & 最初の酸化鉄の重量 & $g$ \\
\hline$W_{1}$ & $t$ 時間後に打ける酸化鉄の重量 & $\mathrm{g}$ \\
\hline$W_{2}$ & $t$ 時間後に打ける固体状塩化物の重量 & $\mathrm{g}$ \\
\hline$W_{3}$ & $t$ 時間後に打ける気体状塩化物の重量 & $\mathrm{g}$ \\
\hline$R$ & 粒子半径 & $\mathrm{cm}$ \\
\hline$\rho$ & 酸化鉄の密度 & $\mathrm{g} / \mathrm{cm}^{3}$ \\
\hline$\alpha$ & $\frac{\mathrm{Fe}_{2} \mathrm{O}_{3}}{2 \mathrm{FeCl}_{3}}$ (重量換算係数) & - \\
\hline$m^{*}$ & 熱天科の減量率 & - \\
\hline
\end{tabular}

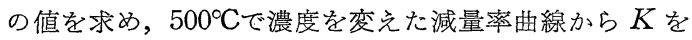
求めて, $\left(C-C^{*}\right)$ と $K$ との関係を示したのが第 3 圀で ある。

以上のように塩化物の揮発現象を分解反応と仮定して 速度式 (7) と（8）から大略実験の結果を説明したが， この仮定を実証するための検討が今後に残されている。 記 号

1) L. Reeve : J. of the Iron and Steel Institute, Sep., 1955, p. 26

2）矢木 - 国井:工業化学雑誌，54，1 (1951)；56, 131，134 (1953)

3) 藤重 : 工業化学雑誌, 66, 891 (1963)

4) H. Schäfer : Zeitschrift für anorganische Chemie, 1949, 259, p. 53

\section{2 脱砒に関する基礎的研究}

$\begin{array}{llll}\text { 九州大学工学部教授・工博 } & \text { 伊藤 } & \text { 尚(正会員) } & \text { 九州大学工学部助教授 杉之原幸夫(正会員) } \\ \text { 九州大学工学部教授・工博 } & \text { 柳ケ瀬 } & \text { 勉(正会員) } & \text { 九州大学工学部助手 } \bigcirc \text { 宮本乙次郎 }\end{array}$

\section{1. まえがき}

鉄鋼原料中に砒素が含有されると, 高炉中で銑鉄中に はいり除去が困難なので，高炉装入前に分離しておかね
ばならない。とくに硫酸滓中には有害な砒素および銅を 含む場合が多いので，製鉄原料とするため，塩化焙烧な ぞで，これらの除去が行なわれているが，砣素の除去は 充分ではなく，したがつて鉄鉱石として使用するには問 